\title{
The impacts of painful noise in the apprehension of sound references on context of a big band
}

\author{
Taciana Ramos Luz ${ }^{\mathrm{a}^{*}}$, Eliza Helena de Oliveira Echternacht ${ }^{a}$ \\ ${ }^{a}$ Department of Production Engineering, Federal University of Minas Gerais , Av. Antônio Carlos, 6627 - \\ Laboratório Integrado de Produção e Saúde (LIPES) - sala 3300, MG, Brazil.
}

\begin{abstract}
This study aims to describe the painfulness applied to situations of teaching-learning of a Big Band in a School of Music of a Brazilian Federal University. Moreover, the concept of what painful noise is will be developed, applied to this context. After Ergonomic Work Analysis [2], the following variables were selected to characterize the painful noise: volume, height, frequency, sound confluence and reverberation. To relate the influence of painful noise on modes operatives, were explained the operative strategies used by teacher and students during the performance in group of this Big Band.
\end{abstract}

Keywords: painful, insalubrities, noise, musicians, Big Band

\section{Introduction}

The object of this study comes from a demand through a mobilization of employees of a Federal University, related to noise arising from the teachinglearning activities, and adversely affects the accomplishment of the administrative activities and the health status of this group. To document these situations, it was carried out a study entitled "Development and Applicability of Concept of painful at Work: a study in the School of Music of UFMG" where were analyzed situations characterized as painful. As a deployment of this study, it became necessary to expand the analysis of painful noise and apply it to the activities of students and teachers that, as well as producing sounds, are also exposed to sounds that spread across the school. The focus was directed to the Big Band of this School of Music.

A Big Band is an instrumental group associated with jazz; that was very popular from years 20 to years 50. Today, Big Bands are found worldwide and are not restricted to the diverse languages of jazz. In Brazil, the Big Bands have spread in the 60's having in their repertoire and musical arrangements dedicated to popular music by Bossa Nova, Samba, Frevo, Salsa, among others. A Big Band has usually 12 to 25 musicians. Primarily contains four suits of instruments: saxophones, trumpets, trombones and the suit that runs predominantly the harmonic basis of the group consisting of: guitar, drums, bass, contrabass and piano [4].

The activities of teaching-learning of music in the School of Music discussed aimed at graduate and post-graduate education and are characterized by its collective character. It is required that the student not only knows how to play their instruments alone, but to be able to play it in an environment of orchestra or Big Band. The student can choose between this two bands or one of them. Therefore, the rehearsals are essential, because they are performance classes that involve group interaction and coordination between the musicians and the conductor.

The snip of the research establishes as empirical field work, situations where the noise appears as overload factor, regardless of its characterization as

E-mail: tacianaluz@hotmail.com 
insalubrious noise. Here we characterize the noise that we name painful noise [5], which requires to reveal the operatory strategies aimed at tackling the problem and impacts on the conditions of work performance and physical and mental integrity of individuals.

\section{Methods}

It was performed a literature review about the painful [3, 6-7] and identified the following factors: (1) the failure of guidelines on the definitions guided on generic categories, such as "wear and tear physical and mental", "excessive concentration "," hard work, difficult, troublesome, uncomfortable, painful and rough" and (2) the relevance of conceptual and methodological frameworks of the ergonomics of the activity [8] approaches to instrumentation about the painful work. Considering the above reference, we establish the following premises:

- The painful work is characterized by overload of operative situations, involving the physical and / or mental work activity; - The painful working situations are set by factors beyond the fields of possibilities to regulations individual and / or collective, inherent in the work activity, generates negative impacts on the performance conditions and may have effects on physical and / or mental health.

To understand the context of the situations of teaching-learning at the School of Music, we applied the Ergonomic Analysis of Work [2]. Were made about 30 visits to the School of Music during the period from June 2009 to May 2011.

First, were observed several instances of teaching and learning to define the focus of analysis, including the observation of individual performance, theoretical and group studies (Symphony Orchestra and the Big Band of the University). Beyond interviews with the director of this school, teachers of various instruments such as viola orchestra, trombone, piano, violin, flute and the teachers and rulers of the Big Band and Symphony Orchestra in order to collect data about the reality of local.

The choice of the university's Big Band was based on the criteria of criticality, related to problems in the operative comfort and workload. Following previous observations made throughout the School of Music, it was observed that the characteristics of the instruments that make up the Big Band, its repertoire, which requires the production of sounds very vigorous and intense, and the inadequacies of the local acoustic essays, generate operative overload, which reflects the critical work situations within this group.

Observations were made and the course of action analysis of the performances of students in a situation of Big Band rehearsal, interviews with all members of this group of students (14 members total) and collection verbalizations. In the interviews, questions were developed related to the observations made by the authors of the study conducted during the rehearsal of that day. The research was carried out in places where the rehearsals of the Big Band, in the auditorium of the School and in a rehearsal room.

In addition, were made records in photo and video from school and students performing. All procedures were performed with permission, after signing a Term of Consent.

\section{Results}

\subsection{The production of noise in the context of rehearsals of the Big Band}

The criticality of the work situations in a Big Band is related to the following factors:

- The characteristics of the instruments that make up the Big Band, like most of the Big Bands, is comprised of saxophonists, trombone, trumpet, guitar, percussion, electric bass and keyboard. Except for the keyboard, these instruments produce sounds of high intensity, among them, stands out the trumpet that produces high-pitched sounds, intense and has a bell which allows a directional spread, causing nuisance to players located in front of them. - The repertoire includes jazz and popular Brazilian music with vigorous rhythms and intense, which in most cases, require much of the sound capabilities of instruments;

- Inadequacies of the acoustic rehearsals places. The Auditorium of the School promotes sound reverberation for having a high ceiling that contributes to the occurrence of the confluence of sounds. Although, the rehearsal room has some acoustic treatment devices for absorption, however, has small dimensions for the number of components of the Big Band, consequently, there are reflections and confluences of sound loud from various instruments. 
Table 1

Impacts on performance and operational strategies

\begin{tabular}{|c|c|c|}
\hline Problems & Operative Strategies & Verbalizations \\
\hline $\begin{array}{l}\text { Difficulties in the perception of sounds } \\
\text { produced by the own instrument. }\end{array}$ & $\begin{array}{l}\text { Repositioning of speakers near the ear of } \\
\text { the musician. }\end{array}$ & $\begin{array}{l}\text { "Especially in this auditory, have a very bad } \\
\text { resonance. If I turn the box I really can not get } \\
\text { back the sound that I produce, therefore, have to } \\
\text { turn the box over in my ear." Student of piano and } \\
\text { keyboard player of the Big Band }\end{array}$ \\
\hline $\begin{array}{l}\text { Loss of sound references from other } \\
\text { instrumentalists. }\end{array}$ & Exacerbation of gestures of the Regent. & $\begin{array}{l}\text { "You can not listen to other musicians, because the } \\
\text { sound is muddy." Guest bassist Big Band } \\
\text { "The gestures are our salvation." } \\
\text { Teacher and conductor of the Big Band }\end{array}$ \\
\hline $\begin{array}{l}\text { Need for equalization of the sounds. The } \\
\text { sound of the instruments to be } \\
\text { highlighted during stretches. }\end{array}$ & $\begin{array}{l}\text { Frequent interruptions to equalize and } \\
\text { increase in the repetition of musical } \\
\text { passages. }\end{array}$ & $\begin{array}{l}\text { "Sometimes there's a part that has an instrument } \\
\text { that has to highlight that point there, but you only } \\
\text { hear muddy sounds and then have to highlight that } \\
\text { which is not appearing. I have to stop and ask to } \\
\text { equalize, who not doing the most important, to try } \\
\text { to listen to each other there is a very difficult. } \\
\text { With this poor acoustics of who is there to listen to } \\
\text { others who are in front without microphones." } \\
\text { Teacher and conductor of the Big Band }\end{array}$ \\
\hline $\begin{array}{l}\text { The sounds are not adequately absorbed } \\
\text { into the auditorium, thus, reverberate and } \\
\text { stay longer in place and mingle with the } \\
\text { sounds produced by other instruments. }\end{array}$ & $\begin{array}{l}\text { Teacher asks students to play more } \\
\text { "dry", in other words, to prolong the least } \\
\text { played notes. }\end{array}$ & $\begin{array}{l}\text { "In the auditorium reverberation is greater, so } \\
\text { usually we ask to touch drier notes because it } \\
\text { sounds too much. Then, the end result can be a } \\
\text { muddy thing, an indefinite sound, blending } \\
\text { harmony with one another that causes a third thing } \\
\text { which is not exists in music." } \\
\text { Conductor and professor at the Big Band } \\
\text { "In a room that reverberates is very uncomfortable, } \\
\text { just what we do in these types of room, we de- } \\
\text { crease the value of banknotes to compensate, to } \\
\text { have a balance of reverb." } \\
\text { Student Trumpet }\end{array}$ \\
\hline
\end{tabular}

\subsection{Impacts of noise on performance and operational strategies developed}

These factors mentioned above generate influence on operational modes of the musicians and conductor of the Big Band to deal with influences from other sounds and instruments and can affect individual and collective performance (see table 1).

\subsection{Elements of sound that characterize painful noise in the context analysed}

The intensity of sound is an important element in the detection criteria of Noise-induced hearing loss. In Norm n.15 (NR-15) of the Ministério do Trabalho e Emprego (MTE) [1], were established tolerance limits for continuous and intermittent noise based on exposure time, inversely proportional to the noise level in $\mathrm{dB}$. For example, for a period of 8 hours, the intensity levels should not exceed $85 \mathrm{~dB}$.

To characterize the painful noise in the context of Big Band, it was necessary to use other elements of musical sound in order to describe the characteristics of these sounds and a definition of how these factors influences on the operative modes. The elements are:

\subsubsection{Volume}

The variable volume - subjective term used to describe the characteristics involving the musical tone frequency, intensity, duration, harmony, sound tissue textiles, space resources and environmental 
conditions - it is more appropriate because it is related to the intensity sensation of a sound in an environment.

\subsubsection{Height and frequency of the sound}

The height is related to the differentiation between bass and treble. Since the frequency describes the number of vibrations per unit time, in other words, a higher pitch presents greater frequency and height, and bass sound, lower height and frequency. These factors determine the operative nuisance; more acute instruments, as the trumpet and saxophone, were reported by components of the Big Band, as major generators of discomfort during the performance.

\subsubsection{Sound confluence}

It occurs when sounds from different instruments blend. The School of Music dependencies analyzed favors the confluence, as the sounds arising from adjacent rooms and group study are not properly absorbed and dissipate to the study environments.

\subsubsection{Reverberation ${ }^{1}$}

The sound propagates in space and the reverberation in excess is a result of inadequacies in space. During the rehearsals of the Big Band in the auditorium and rehearsal room, the sound waves produced by different instruments at high intensity and varying frequencies can not find a surface that absorbs most of its energy. Therefore, a sound mass is formed which interferes in the capture of reference sounds by musicians and generate impacts on their operating modes.

\section{Discussion and conclusion}

The high volume of sounds produced in the Big Band added to the high frequencies, heights of acute instruments, the sound confluence and the reverberation, coming from the various instruments that make up the Big Band in rehearsals environments, characterize the painful noise of the

\footnotetext{
${ }^{1}$ Reverberation occurs when a sound wave in contact with a surface reflection suffers because of incomplete absorption wave The reverberation time depends on the size, the absorption level of the floor, walls, furniture and people in place. So, is due to poor environmental conditions for activities to be performed there.
}

point of view of Big Band. Considering the assumptions adopted for the characterization of the painful, the painful noise is a factor to be considered in this context, in view that:

The occurrence of painful noise causes situations of overload sound, because some sounds become noise to musical practice. However, the operative strategies seek to compensate for difficulties arising from overload of sound, but other elements can cause operative overload.

Teachers and students don't have any means to regulate the painful noise and its potential effects on health since "try to get used" to the situation.

\section{References}

[1] ABNT - Asociação Brasileira de Normas Técnicas- NR 15 - Atividades e Operações Insalubres. Rio de Janeiro, 2000

[2] Guérin et.al.. Compreender o trabalho para transformá-lo, $1^{\mathrm{a}}$ ed. SP: Edgard Blucher, 2001.

[3] Kleinubing, VP. Decreto $n^{\circ} 4.307$, de 28 de fevereiro de 1994

[4] Khron, KE. Ella Fitzgerald: First Lady of Song. TwentyFirst Century Books, 2001. 97 p.

[5] Luz, TR; Echternacht, EHO. Desenvolvimento e Aplicabilidade do conceito de Penosidade no Trabalho: um estudo na Escola de Música da UFMG. Anais: XVI Congresso Brasileiro Ergonomia 2010.

[6] Paim, P. Projeto de Lei n. 1.015/8812 art. $1^{\circ}$.

[7] Sato, L. Conceito de trabalho penoso. Revista CIPA, v. 15, n. 179, p. 41,1984

[8] Wisner, A. Réflexions sur L'ergonomie. Toulouse: Octarès, 1993. 